\title{
ゾルーゲル電気泳動電着法により作製した酸化チタン皮膜の光触媒活性
}

\author{
黑崎 崇敏, 中川 玲, 飯村 修志, 吉原佐知雄, 白樫 高史 \\ 宇都宮大学大学院工学研究科エネルギー環境科学専攻（†321-8585 宇都宮市陽東 7-1-2）

\section{Photocatalytic Properties of Titanium Oxide Coating Prepared by Electrophoretic Sol-Gel Deposition}

\author{
Takatoshi KUROSAKI, Akira NAKAGAWA, Shuji IIMURA, Sachio YOSHIHARA, \\ and Takashi SHIRAKASHI
}

\begin{abstract}
Department of Energy \& Environmental Science, Graduate School of Engineering, Utsunomiya University (7-1-2 Yoto, Utsunomiya, Tochigi 321-8585, Japan)
\end{abstract}

\author{
Received April 9, 2002 ; Accepted August 23, 2002
}

\begin{abstract}
In this paper Electrophoretic Sol-Gel Deposition was introduced to immobilize the $\mathrm{TiO}_{2}$ photocatalysis. Thus prepared coatings showed quite high-photocalytic activities without successive heat treatment. It is suggested that Non-heated coating showed high-photocalytic activity because it responds effectively for light, which is attributed to the nanostructure of the deposited coating.
\end{abstract}

Key Words : Titanium Oxide, Electrophoretic Sol-Gel Deposition, Non-heated Coating

\section{1 緒 言}

酸化チタン光触媒は，環境浄化を目的とした様々な分野で 利用されている ${ }^{1)}$ 。酸化チタン光触媒の多種多様な需要の増 加に伴って，その固定化基材の種類や形状による固定化法の 選択などが重要となり，これらの解決が，現在の酸化チタン 光触媒に扔ける研究課題の一つとなっている。

酸化チタン光触媒膜を作製する際，固定化法によっては基 材が高温に熱せられたり，熱処理を施す場合が多く，充分な 光触媒機能を有する酸化チタン膜を低温, 特に室温付近の温 度で合成・固定化したという報告例は少ない，低温合成法と して知られているゾルーゲル法であっても，充分な光触媒機 能を有する酸化チタン膜を得るためには，数百度の熱処理を 必要とする。

酸化チタンを含むセラミックスの電気泳動は, 溶媒中にセ ラミックスの粒子を带電・分散させたものや酸化物等のゾル 溶液に電極を浸漬させ電場を印加することによりセラミック ス粒子を電極基板上に直接堆皘させる手法2)である．本報で は, チタニアゾル溶液から電気泳動法によって導電性基材に 固定化 ${ }^{3)}$ した酸化チタンが, 熱処理を施さなくても良好な光 触媒活性を得ることができたので，これを報告する．

\section{1 チタニアゾル溶液の調製}

\section{2 実験方法}

チタニアゾル溶液は，チタンテトライソプロポキシド（岸 田化学, 特級) に溶媒のイソプロピルアルコール（岸田化学, 特級）と水を $17: 3: 80$ の重量比で加えて, さらにこの混合 液 $100 \mathrm{~g}$ に対して濃硝酸（岸田化学, 特級) $3 \mathrm{~g}$ の割合で加 えて調製した。十分に加水分解と重縮合をさせた後，それを
重量比で 10 倍に希釈したものを電解液とした。

\section{2 ゾルーゲル電気泳動電着法による皮膜の作製}

アセトンにより脱脂を施したステンレス基板と白金板をそ れぞれ陰極，陽極として調製したチタニアゾル溶液中に浸し， 定電圧電解法によりコーティングを行った．作用極であるス テンレス板はマスキングテープ（日東電工，N-300）により マスキングして，反応面積 $4 \mathrm{~cm}^{2}$ とし，対極は白金板（20× $20 \times 0.5 \mathrm{~mm}^{3}$ ) を用いた。電解により析出した皮膜を常温乾

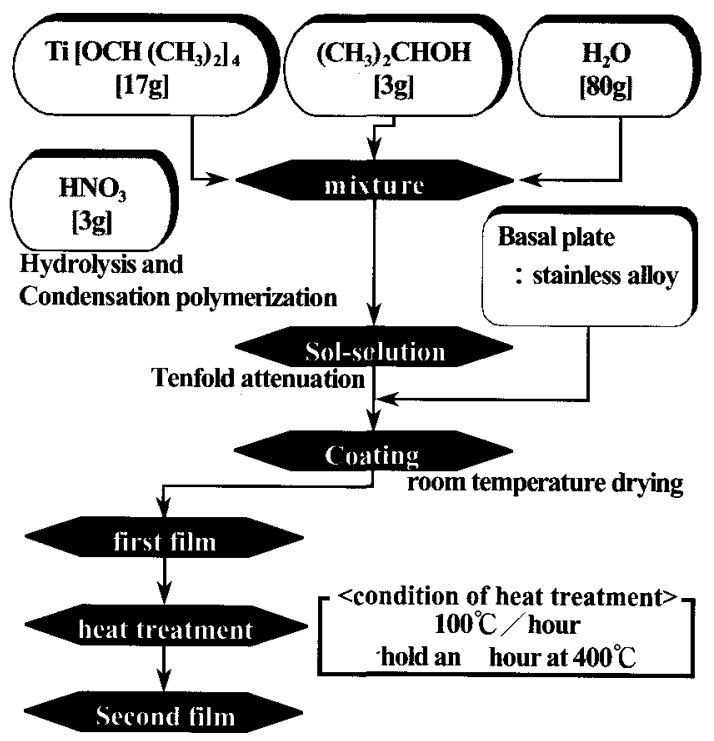

Fig. 1 Preparation method of $\mathrm{TiO}_{2}$ films by Electrophoretic Sol-Gel Deposition. 
燥したものを一次皮膜, その後熱処理を施したものを二次皮 膜として各種評価を行った。熱処理方法は, 電気炬 (YAMATO SCIENTIFIC, Muffle Furnace FP32) を用い て, 空気雰囲気中で $100^{\circ} \mathrm{C} /$ hour の昇温速度で $400^{\circ} \mathrm{C}$ まで昇 温, 1 時間保持し, その後, $100^{\circ} \mathrm{C} /$ hour で冷却した.

\section{3 光触媒活性の評価方法}

作製した皮膜の光触媒活性は, $\mathrm{CH}_{3} \mathrm{CHO}$ の気相分解反応 で評価した，石英ガラス製光学窓を有するガラスセルを使用 し， $\mathrm{CH}_{3} \mathrm{CHO}$ のセル内濃度が一定となるように注入した後， 光照射を行い, 経時的にマイクロシリンジでサンプリングし ガスクロマトグラフ（SHIMADZU GC-14B）によりセル内 濃度を定量した。

\section{1 非加熱皮膜の光触媒活性}

\section{3 結果及び考察}

各電解電圧で処理した電極の表面形状は，10 Vでは皮膜 をほとんど形成しなかったが，20V以上印加電圧を高くし ていくほど均一な白色皮膜を形成するようになった。この熱 処理前皮膜を用いて光触媒活性の評価を行った. その評価結 果を石原産業製酸化チタン：ST-01に対する結果と合わせて Fig. 2 に示す. 系内のアセトアルデヒド濃度を的 500 ppm として光照射を行ったところ, 印加電圧 $20 \mathrm{~V}$ 以上で作製し た皮膜がほぼ同程度の良好な活性を示した。これらの試料は， 同系で測定したST-01 の光触媒活性よりも高活性を示すこと がわかった。

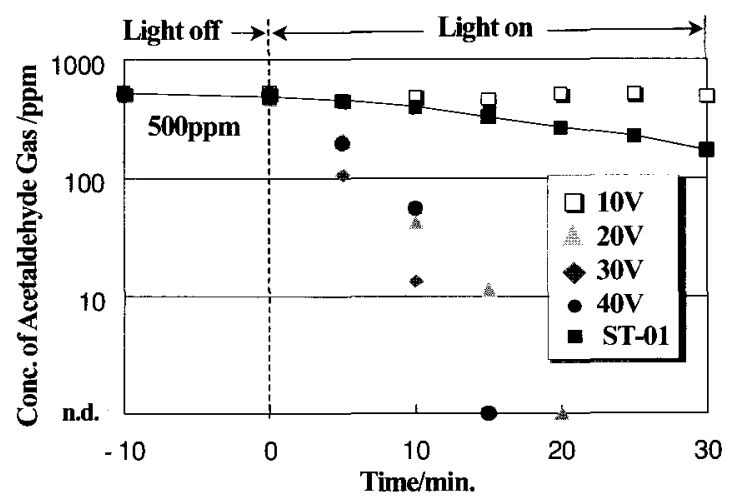

Fig. 2 Time dependence of the concentration of the acetaldehyde gas remaining in the cell under illumination of Xenon lamp.

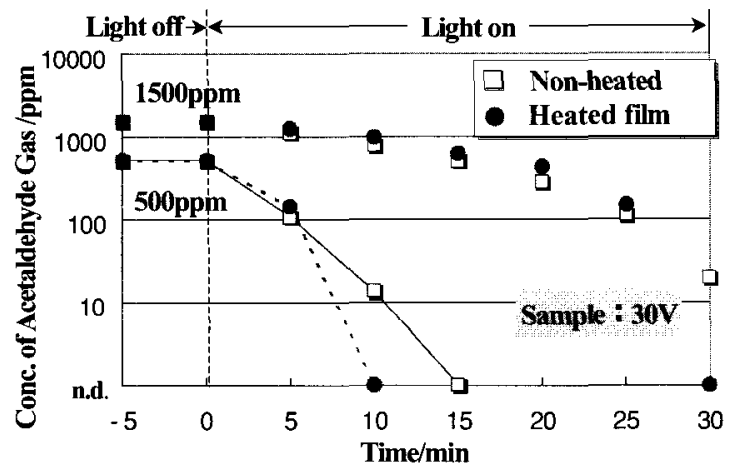

Fig. 3 Time dependence of the concentration of the acetaldehyde gas remaining in the cell under illumination of Xenon lamp.

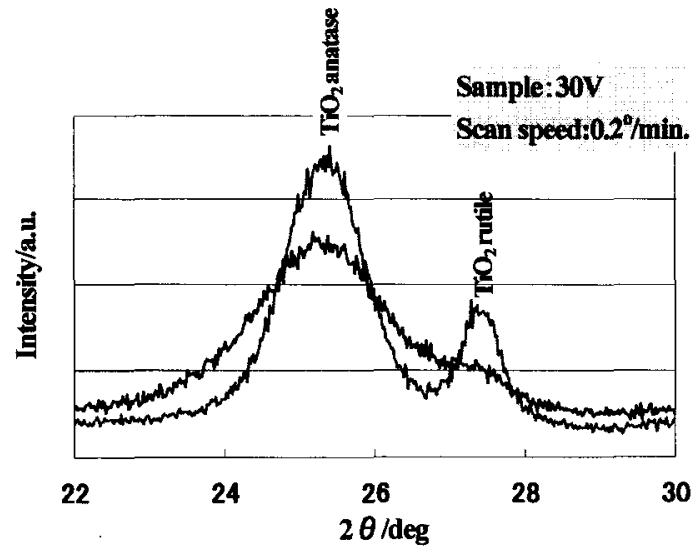

Fig. 4 X-ray diffraction patterns of $\mathrm{TiO}_{2}$ films obtained by with or without heat treatment. The lines - and - denote with heat treatment, without heat treatment, respectively.

Table 1 Primary particle's size of $\mathrm{TiO}_{2}$ anatase crystals estimated by X-ray diffraction patterns of $\mathrm{TiO}_{2}$ films obtained by with or without heat treatment.

\begin{tabular}{cccc}
\hline & $2 \boldsymbol{\theta}[\mathrm{deg}]$ & $\mathrm{B}[\mathrm{deg}]$ & $\mathrm{D}[\AA]$ \\
\hline Non-heated film & 25.18 & 1.84 & 43.2 \\
\hline Heated film & 25.4 & 1.24 & 64.7 \\
\hline
\end{tabular}

また，熱処理前後で光触媒活性の評価を行った。印加電圧 $30 \mathrm{~V}$ で作製した皮膜を用いて，初濃度 $500 \mathrm{ppm}$ と 1500 ppmから評価を行い，熱処理後，再び同様の評俩を行った. その評価結果を Fig. 3 に示す. 光触媒活性は, 熱処理を施し てもほぼ変化はなく, 初濃度の変更によってその傾向が変わ ることはなかった。

ゲル膜の熱処理は，膜の緻密化・結晶化を起こす4!. 加水 分解と重縮合により高分子化したチタニア化合物は, 電気泳 動により電極表面に堆積し，多結晶体として固定化する。多 結晶体中の 1 次粒子は, Ti $\left[\mathrm{OCH}\left(\mathrm{CH}_{3}\right)_{2}\right]_{4}$ の数分子が加水分 解と重縮合を起こした数 $\mathrm{nm} の$ 粒子であると報告されてい る ${ }^{2)}$. 光触媒では，一般に，粒子サイズが小さいほど再結合 確率が減少し，光触媒活性が高いと言われている.また，熱 処理によって 1 次粒子同士が結合し, 粒子の緻密化・結晶化 が起こる.X 線回折装置 (理学電気(株), RINT2000 AFC-7) による測定から，本法で作製した皮膜の結晶構造にも同様の 傾向が見られた. Fig.4のように熱処理前の皮膜は，ほほ

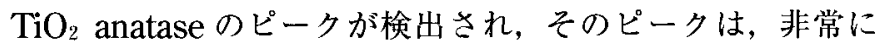
幅広であった．熱処理後は， $\mathrm{TiO}_{2}$ anatase のピークが鋭く なり, $\mathrm{TiO}_{2}$ rutile のピークも検出された. また, $\mathrm{TiO}_{2}$ anataseのピークから以下の式に示す Scherrerの式を用いて $\mathrm{TiO}_{2}$ の粒子サイズを求めた. その算出結果を Table 1 に示す.

$$
D=K \cdot \lambda /(B \cdot \cos \theta)
$$

ここで $D$ は粒子サイズ, $K$ は Scherrer 定数, $\lambda$ はX 線 の波長， $B$ は半值幅， $\theta$ はX線入射角である.これより， 作製した $\mathrm{TiO}_{2}$ 皮膜の粒子サイズは，数 $\mathrm{nm}$ オーダーであ り，400 $\mathrm{C}$ の熱処理で粒子サイズが増大していることが分か る.ゾルーゲル法電気泳動電着法により固定化した酸化チ夕 ン皮膜は, 超微粒子で構成され, 高分子化したチタニア粒子 


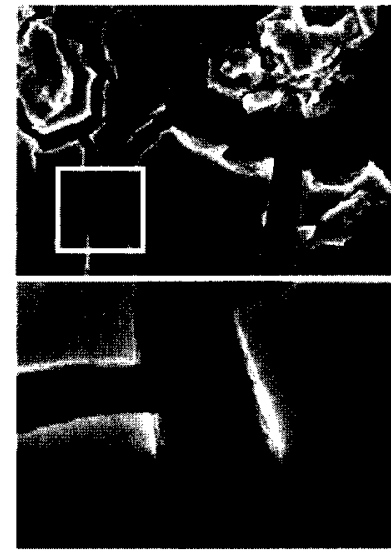

30V: Non-heated

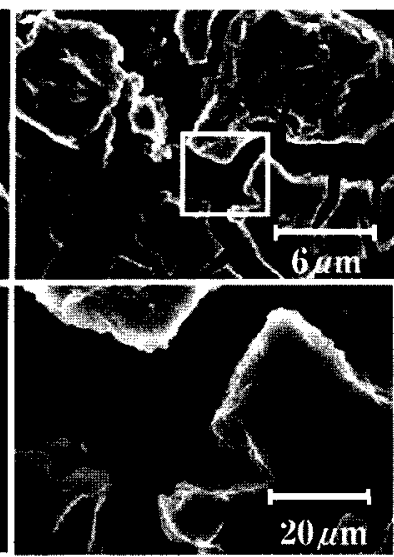

30V: Heated film
Fig. 5 SEM photographs for the surface of Non-heated film or Heated film.

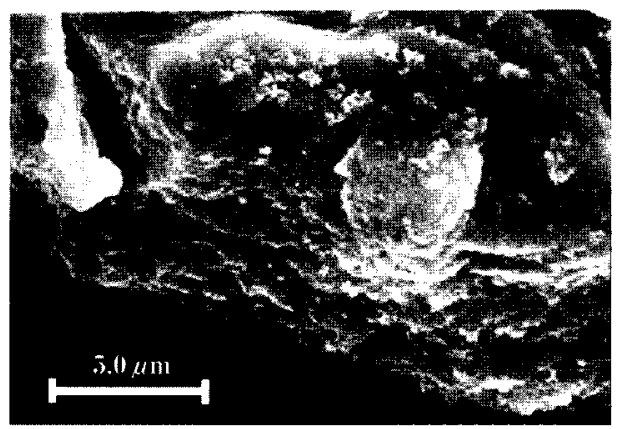

Fig. 6 SEM photograph for the surface of Non-heated film: $30 \mathrm{~V}$.

の堆積物でありながら，アナターゼ型の結晶性を有すること がわかった。このチタニア粒子のアナターゼ型の結晶性は, ゾル溶液の吸収スペクトル測定から，チタニア粒子がゾル溶 液中に分散している状態で形成していることが示唆されてい る. 加水分解と重縮合反応によってアナターゼ型の結晶性を 有したチタニアの微粒子が溶液中で形成され，これが電気泳 動によって基板上に堆積・固定化することで，光触媒活性の 高い皮膜が得られたと考えられる，一方，この皮膜に熱処理 を施すと, アナターゼ型酸化チタンの結晶性が向上するもの
の，それに伴う膜の緻密化によって表面積が減少し，また， 粒子サイズの顕著な違いは見られず，ルチル型の成長もある ために，見かけの光触媒活性は，熱処理前後でほぼ変化しな かったと考えられる。

\section{2 皮膜表面構造の解析}

作製した皮膜の表面構造の解析は，FE-SEM（日立製作所， S-4500）を用いて, 皮膜表面の観察を行った。一般に生成し たゲル厚膜の乾燥や熱処理は，溶媒の蒸発，膜の緻密化・収 樎, 基板との熱膨張係数の差による引張り応力あるいは压縮 応力によって亀裂発生や膜の剥離が起こる ${ }^{4}$. Fig. 5 に示す ように本法で作製した皮膜も亀裂を有していることが分かっ た. 熱処理前の皮膜からも亀裂が確認できるため, 電解後の 常温乾燥のとき, 又は電解中に亀裂が発生していると考えら れる．また，熱処理前後で試料の表面形状に大きな変化は見 られず，熱処理によって皮膜の巨視的な変化は見られなかっ た. 亀裂部分を拡大したSEM 像を Fig. 6 に示す。この亀裂 部分の形状から，皮膜は層状に形成されていると考えられ， その厚みは数 $\mu \mathrm{m}$ から数十 $\mu \mathrm{m}$ であることが確認できる. ま た，このような形状は，光触媒活性において表面積効果によ る高活性化が期待できる.

\section{4 結 言}

ゾルーゲル電気泳動電着法により作製した酸化チタン光触 媒皮膜は，熱処理を施さなくてもST-01より良好な光触媒活 性を示した、ゾル溶液中でアナターゼ型の結晶を有する超微 粒子を形成したチタニア粒子が厚膜の形で固定化されたこと で，このような光触媒活性の高い皮膜が得られたと考えられ る.

この研究は、文部科学省科学研究費補助金特定領域研究 (A) (No. 14050019) によった。

\section{文 献}

1) 藤嶋 昭, 橋本和仁, 渡部俊也, 光クリーン革命, CMC (1997).

2) P. Sarkar and P. S. Nicholson, J. Am. Ceram. Soc., 79, 1987 (1996).

3） 中谷康弘, 柳田祥三, 特開平 11-310898 (1999).

4）作花済夫, ゾルーゲル法応用技術の新展開，CMC (2000). 